\title{
An amphilestid-grade eutriconodontan from the Middle Jurassic of Russia
}

\author{
Alexander O. Averianov, Alexey V. Lopatin \& Sergei A. Krasnolutskii \\ ABSTRACT. An isolated upper molariform tooth from the Middle Jurassic Itat Formation at Berezovsk \\ Quarry, Krasnoyarsk Territory, West Siberia, Russia, is identified as Eutriconodonta indet. By low \\ angulation of the main cusps, reduction of the labial cingulum, and interrupted lingual cingulum it is similar \\ with anterior upper molariform teeth (M1-2) of Gobiconodontidae. This taxon may belong to the oldest \\ gobiconodontid which have not been reported previously from the Jurassic.
}

KEY WORDS: Eutriconodonta, Middle Jurassic, Siberia.

Alexander O.Averianov [lepus@zin.ru],Zoological Institute, Russian Academy of Sciences, Universitetskaya nab. 1, Saint Petersburg 199034, Russia; AlexeyV. Lopatin [alopat@paleo.ru], Paleontological Institute, Russian Academy of Sciences, Profsouznaya ul. 123, Moscow 117997, Russia; Sergei A. Krasnolutskii [krasnolucki.ser@mail.ru], Sharypovo Regional Museum, 6 microraion, Sharypovo 662311, Krasnoyarsk Territory, Russia.

\section{Эутриконодонт амфилестидного уровня организации из средней юры России}

\section{А.О. Аверьянов, А.В. Лопатин, С.А. Краснолуцкий}

\begin{abstract}
РЕЗЮМЕ. Изолированный верхний молярообразный зуб из среднеюрских отложений итатской свиты Березовского карьера в Красноярском крае (Западная Сибирь, Россия) определен как принадлежащий Eutriconodonta indet. По отсутствию выраженной триангулярности главных бугорков коронки, отсутствию лабиального цингулюма и прерванному лингвальному цингулюму данный зуб похож на передние верхние молярообразные зубы (M1-2) Gobiconodontidae. Зуб может принадлежать древнейшему представителю гобиконодонтид, которые раньше не были известны из юрских отложений.
\end{abstract}

\section{КЛЮЧЕВЫЕ СЛОВА: эутриконодонты, средняя юра, Сибирь.}

\section{Introduction}

Eutriconodontan mammals share with other "triconodontans", the morganucodontans, linear arrangement of the main cusps of the molar teeth, but more derived in the skull structure. Eutriconodontans were common elements in the Jurassic mammal faunas of Europe and North America and especially flourished in the Early Cretaceous of Asia. In the Late Cretaceous few eutriconodontan taxa persisted only in North and South America. This group did not survive the K/T boundary.

The Eutriconodonta could be divided into two levels of organization: the amphilestid grade (families Amphilestidae, Klameliidae, Gobiconodontidae, and Austrotriconodontidae) and triconodontid grade (Triconodontidae). The first grade is characterized by the principal cusp of the molars higher than side cusps and embrasure tooth occlusion, when the main cusp occludes more or less between the opposite molars. In the second grade the side cusps of the molars are almost as high as the principal cusp and the molars occlude with the opposite molars "one-to-one."
The Asiatic record for the Jurassic Eutriconodonta is relatively poor, particularly because of our little knowledge of Middle and Late Jurassic Asiatic mammal faunas. Two genera of Klameliidae are known from the Middle Jurassic of China and Kyrgyzstan (Chow \& Rich, 1984; Martin \& Averianov, 2007). The Middle Jurassic Liaotherium from China, originally described as an amphilestid (Zhou et al., 1991), can be actually a "symmetrodontan" (Averianov, 2002). Unidentified amphilestid and triconodontid have been reported recently from the Middle Jurassic of Kyrgyzstan based on isolated tooth fragments (Martin et al., 2007).

Here we describe the first eutriconodontan from the recently emerging mammal fauna of Itat Formation (Middle Jurassic, Bathonian) of the south of Krasnoyarsk Territory in West Siberia, Russia. This fauna included previously tegotheriid docodontan Itatodon, indeterminate docodontans, a dryolestid, and an amphitheriid stem zatherian Amphibetulimus (Averianov et al., 2005a; Lopatin and Averianov, 2005, 2006, 2007; Averianov and Lopatin, 2006), as well as other mammals which will be described elsewhere.

Collection abbreviation. PIN - Paleontological Institute of the Russian Academy of Sciences, Moscow, Russia. 


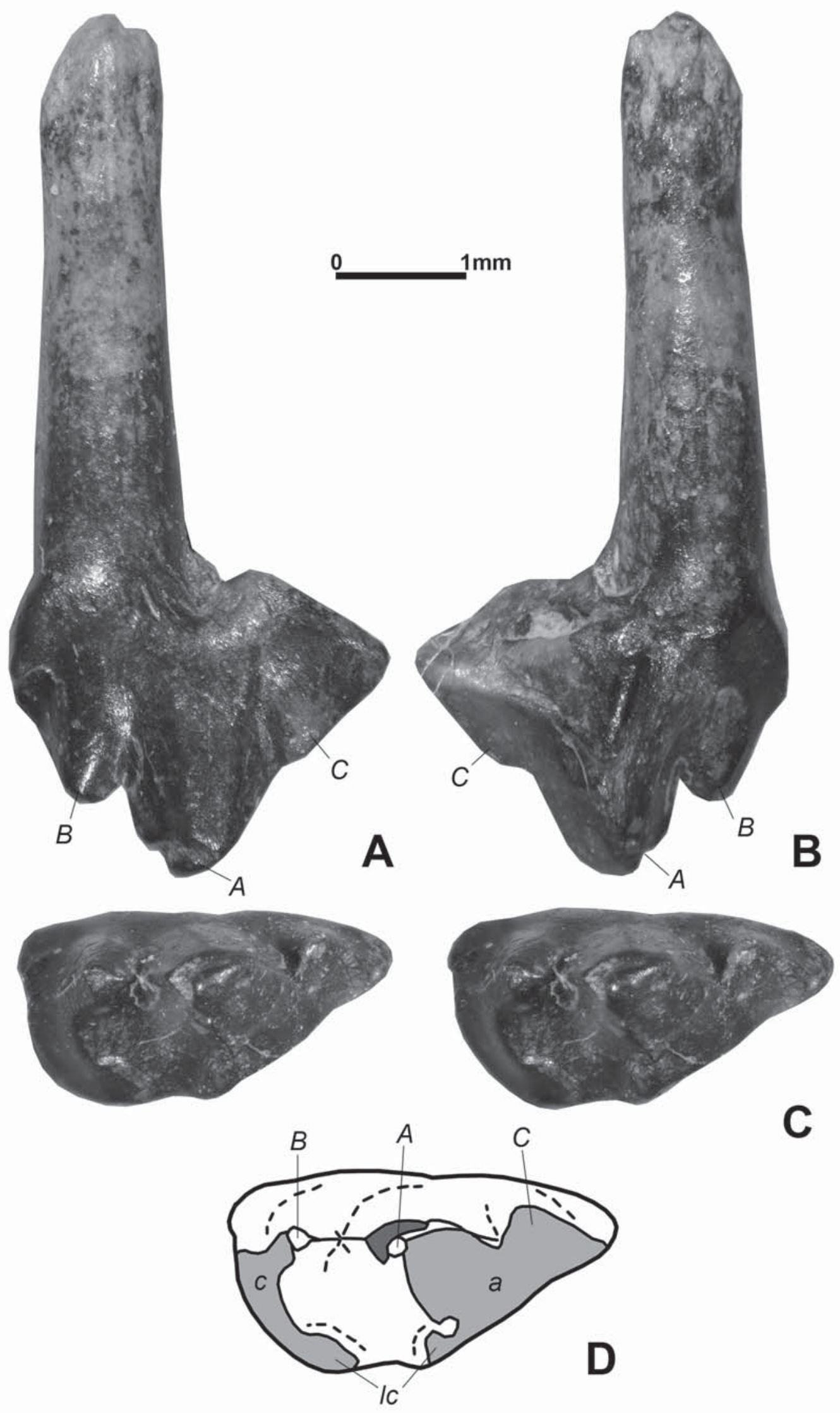




\section{Systematic Paleontology}

\author{
Eutriconodonta Kermack et al., 1973 \\ Eutriconodonta indet.
}

Fig. 1.

Material. PIN 5087/4, left upper molariform tooth. Berezovsk Quarry, near Nikol'skoe village, Sharypovo District, Krasnoyarsk Territory, Russia; upper part of Itat Formation, Middle Jurassic (Bathonian).

Description. The tooth is relatively large with massive crown and long robust roots (only mesial root is preserved). The main cusp $A$ is about twice higher than the side cusps $B$ and $C$. The most of the cusp $C$ is eliminated by wear. Because of this wear, the cusp angulation can be only approximately evaluated $\left(\sim 165^{\circ}\right)$. The axes of the side cusps are slightly diverging from the axis of the main cusp. On the mesial side there is a slight embayment of the crown but there are no cingular cusps in this region. The labial cingulum is completely lacking. The lingual cingulum, mostly eliminated by wear, was rather strong and interrupted in the middle opposite to the main cusp $A$. There are two large wear facets on the lingual crown side which remove considerable size of the crown enamel and dentine. A smaller one is mesial, produced by the lower molariform cusp $c$, and is along the mesial side of the cusp $B$ and the mesial half of the lingual cingulid. A larger facet, produced by the main cusp $(a)$ of the lower molariform tooth, is extending along the distal half of the lingual cingulum, distal side of the cusp $A$, and lingual side of the cusp $C$. The enamel is smooth, without striations.

Measurements. Crown length $2.9 \mathrm{~mm}$, crown width $1.5 \mathrm{~mm}$.

Comparison. The great size differential between the main and side cusps and embrasure wear pattern when the main cusp of lower molariform tooth $(a)$ occluded between the upper molariform cusps $A$ and $C$ suggests reference of PIN 5087/4 to the amphilestid grade eutriconodontans (Amphilestidae, Klameliidae, and Gobiconodontidae) rather than to the Triconodontidae. The upper dentition is not known for the Klameliidae, but lack of enamel striation (Martin \& Averianov, 2007) safely removes PIN 5087/4 from that group. The upper dentition of Amphilestidae is known from only two isolated molariforms referred to the Middle Jurassic Amphilestes broderipii (Owen, 1845) (Freeman, 1979: pl.16, figs.1-2; Averianov et al., 2005b: 4) and to the Early Cretaceous Kemchugia magna Averianov et al., 2005 (Averianov et al., 2005b: fig.2A-C). Both teeth have strong cingulum around the whole crown and therefore lack of a labial cingulum in PIN 5087/4 pre- cludes its attribution to the Amphilestidae. In the Gobiconodontidae the complete cingulum is best developed in the posterior molariforms (M3-5) while in the anterior molariforms (M1-2) it can be variously interrupted. In the gobiconodontids the posterior molariforms further differ from the anterior ones by more transversely wide crown and more angulated main cusps. Structurally PIN 5087/4 is most similar with the anterior molariforms of Gobiconodontidae. Another gobiconodontid trait, observable in PIN 5087/4, is diverging of the side cusp's axes from the main cusp's axis.

\section{Discussion}

A complete absence of cingulum from one crown side (labial) is characteristic for the lower molariforms of the Amphilestidae (although quite a strong labial cingulid may be present in some lower molariforms of the Middle Jurassic Phascolotherium bucklandi (Broderip, 1828) [pers. obs. by AA]). But lower molariforms wear from the labial side so their lingual cingulid never becomes worn. The only cingulum which undergone wear is the lingual cingulum of the upper molariforms and thus identification of PIN 5087/4 as an upper molariform is without doubts.

According to the recent phylogenetic analysis by Rougier et al. (2007) the Eutriconodonta is paraphyletic, not natural group because the Gobiconodontidae and Amphilestidae are more closely related to the line leading to tribosphenic mammals than to the Triconodontidae, a predictable and awaiting result. However, for the sake of classification, we continue to use here the concept of Eutriconodonta.

PIN 5087/4 presents the first discovery of a eutriconodontan mammal in the Jurassic of Siberia and Russia. Previously in our country only remain of a Jurassic morganucodontan has been found (Gambaryan \& Averianov, 2001). It is a notable addition to the poor Asiatic record of the Jurassic eutriconodontans. Most intriguing is the supposed gobiconodontid affinities of PIN 5087/4. This group, flourished in Asia during the Early Cretaceous, has not been recorded previously from the deposits of Jurassic age. PIN 5087/4 may belong to the oldest member of Gobiconodontidae, but for its characterization an additional material is greatly needed.

ACKNOWLEDGEMENTS. This study was supported by the Board of the President of the Russian Federation (MD-255.2003.4, MD-3050.2007.4, NSh-6228.2006.4), the Russian Foundation for Basic Research (project nos. 04-0449637, 04-04-49113, 05-04-48493, 07-04-00393), and the Russian Science Support Foundation.

Figure 1. Eutriconodonta indet., PIN 5087/4, left upper molariform tooth in labial (A), lingual (B), and occlusal (C, stereopair) views. Berezovsk Quarry, Sharypovo District, Krasnoyarsk Territory, Russia; Itat Formation, Middle Jurassic (Bathonian).

Abbreviations: $A, B, C$ - main crown cusps; $l c$ - lingual cingulum. Wear facets produced by the cusps $a$ and $c$ of the lower molariform teeth are indicated by lighter grey. A brakeage of the crown near the tip of the cusp $A$ is shown by darker grey. Scale bar is $1 \mathrm{~mm}$. 


\section{References}

Averianov A.O. 2002. Early Cretaceous "symmetrodont" mammal Gobiotheriodon from Mongolia and the classification of "Symmetrodonta" // Acta Palaeontologica Polonica. Vol.47. No.4. P.705-716.

Averianov A.O., Lopatin A.V., Skutschas P.P., Martynovich N.V., Leshchinskiy S.V., Rezvyi A.S., Krasnolutskii S.A. \& Fayngerts A.V. 2005a. Discovery of Middle Jurassic Mammals from Siberia // Acta Palaeontologica Polonica. Vol.50. No.4. P.789-797.

Averianov A.O., Skutschas P.P., Lopatin A.V., Leshchinskiy S.V., Rezvyi A.S. \& Fayngerts A.V. 2005b. Early Cretaceous mammals from Bol'shoi Kemchug 3 locality in West Siberia, Russia // Russian Journal of Theriology. Vol.4. No.1. P.1-12.

Averianov A.O. \& Lopatin A.V. 2006. Itatodon tatarinovi (Tegotheriidae, Mammalia), a docodont from the Middle Jurassic of Western Siberia and phylogenetic analysis of Docodonta // Paleontological Journal. Vol.40. No.6. P.668-677.

Chow M.-C. \& Rich T.H.V. 1984. A new triconodontan (Mammalia) from the Jurassic of China // Journal of Vertebrate Paleontology. Vol.3. No.4. P.226-231.

Freeman E.F. 1979. A Middle Jurassic mammal bed from Oxfordshire // Palaeontology. Vol.22. No.1. P.135-166.

Gambaryan P.P. \& Averianov A.O. 2001. Femur of a morganucodontid mammal from the Middle Jurassic of Central
Russia // Acta Palaeontologica Polonica. Vol.46. No.1. P.99-112.

Lopatin A.V. \& Averianov A.O. 2005. A new docodont (Docodonta, Mammalia) from the Middle Jurassic of Siberia // Doklady Biological Sciences Vol.405. P.434436.

Lopatin A.V. \& Averianov A.O. 2006. Mesozoic mammals of Russia // 9th International Symposium on Mesozoic Terrestrial Ecosystems and Biota. Abstracts and Proceedings Volume. Manchester. P.67-70, 165.

Lopatin A.V. \& Averianov A.O. 2007. The earliest Asiatic pretribosphenic mammal (Cladotheria, Amphitheriidae) from the Middle Jurassic of Siberia // Doklady Biological Sciences. Vol.417. P.432-434.

Martin T. \& Averianov A.O. 2007. A previously unrecognized group of Middle Jurassic triconodontan mammals from Central Asia // Naturwissenschaften. Vol.94. No.1. P.43-48.

Martin T., Averianov A.O. \& Pfretzschner H.-U. 2007. Jurassic mammals of Central Asia // Journal of Vertebrate Paleontology. Vol.27. Supplement to No.3. P.113A.

Rougier G.W., Isaji S. \& Manabe M. 2007. Early Cretaceous mammals from the Kuwajima Formation (Tetori Group), Japan, and a reassessment of triconodont phylogeny // Annals of Carnegie Museum. Vol.76. No.2. P.73-115.

Zhou M., Cheng Z.-W. \& Wang Y.-Q. 1991. A mammalian lower jaw from the Jurassic of Lingyuan, Liaoning // Vertebrata PalAsiatica. Vol.29. No.3. P.165-175. 